\title{
Does Electronic Banking Really Improve Bank Performance? Evidence in China
}

\author{
Shaohua Yang ${ }^{1}$, Zeyun $\mathrm{Li}^{2}$, Yaxin $\mathrm{Ma}^{3} \&$ Xingxing $\mathrm{Chen}^{4}$ \\ ${ }^{1}$ Faculty of Business, Information Technology \& Creative Arts, Toi Ohomai Institute of Technology, New \\ Zealand \\ ${ }^{2}$ Geography Section, School of Humanities, Universiti Sains Malaysia, Penang, Malaysia \\ ${ }^{3}$ Ph.D. Student at School of Management, Universiti Sains Malaysia, Penang, Malaysia \\ ${ }^{4}$ Business with Finance, Bachelor of Arts (Honours), University of Northumbria at Newcastle, UK \\ Correspondence: Shaohua Yang, Master of Management, Faculty of Business, Information Technology \& \\ Creative Arts, Toi Ohomai Institute of Technology, New Zealand. Tel. 64-211-718-073. E-mail: \\ samuelyang0713@hotmail.com
}

Received: November 26, 2017

Accepted: December 24, 2017

Online Published: January 5, 2018

doi:10.5539/ijef.v10n2p82

URL: https://doi.org/10.5539/ijef.v10n2p82

\begin{abstract}
This study investigated the performance of Chinese banks following the full adoption of e-banking system, particularly in profitability and cost efficiency performance. The study became more important with the development of e-banking and internet because of increased penetration of e-banking which has redefined the banking operations in China and in globe. Secondary method was adopted in this study. The report and data of five banks in China were used for sample analysis. The bank performance was measured in terms of return on assets (ROA), return on equity (ROE), operating margin (OM), net interest margin (NIM) and efficiency ratio. With the data collected, the different performance means between development stage and developed stage of e-banking in China were compared. The study revealed that e-banking could improve the Chinese bank performance in terms of ROA, ROE, and OM. On the contrary, e-banking has a slight impact on Chinese bank performance with respect to NIM and efficiency ratio. The findings of this study were to provide banks with suggestions for e-banking adoption for banking operations.
\end{abstract}

Keywords: e-banking, bank performance, banking adoption, banking operation

\section{Introduction}

With the significant growth of e-commerce in China, more young people are experiencing e-banking such as e-payment when purchasing products. It is estimated that the value of e-commerce in China will be US\$540 billion by 2015 , and by 2020 will exceed that in the U.S., the UK, Japan, Germany and France combined (Rauf, 2014). This relates to the number of people connected to the Internet in China, be it via computers or smartphones - there are over 600 million internet users and over 500 million mobile internet users in the country (Rauf, 2014). The growing number of the applicants for Internet has also been very crucial in product marketing and distribution in many businesses. Banks not only are one of the early users of internet technology, but also drive the technological revolution (Kondabagil, 2007). Moreover, from the perspective of customer, convenience and a greater range of available products were also found to be important motivators of consumption. Banks need to offer e-banking service to customer via television, computer or phone. E-banking can be classified in terms of the platforms: telephone banking, mobile banking, TV-based banking, online banking (or internet banking), and computer banking (or offline banking) (Mihalciuc, Apetri, \& Bonaventure, 2008). It covers various initiatives such as phone banking, mobile banking, Internet payment system, and Internet banking (Kurnia, Peng, \& Liu, 2010).

In general, the internet not only influences individuals, but also exerts impact on the banking sector. According to Yang, Cheng, and Luo (2009), banking industry is the leader of industries in which e-commerce has been developed. A majority of banks transform from traditional banks to multichannel models. In e-banking, Sumra (2011) finds that the basic functions of e-banking are online transfers, electronic bill payments, and opening a deposit account. E-banking provides services to customers through a bank portal to enter websites anywhere via 
using an equipment with internet, such as computer or pad. Then, a customer code and a password are the basic certificates to receive the internet banking services (Daniela, Simona, \& Paun, 2010). Above studies on this subject have been conducted worldwide to identify that e-banking could improve service quality or provide high-value financial services at lower costs to cross-sell products like loans or credit cards in the absence of physical boundaries. Nonetheless, very limited empirical research is available to define the impact of the internet on the performance of multichannel bank particularly in China. Hence, to enlarge the body of literature on the performance of e-banking under the Chinese context, this study aims to prove the relationship between e-banking and bank performance in China as well as how e-banking affects bank performance. The primary purpose of this study is twofold. Firstly, the relationship between the e-banking adoption and bank performance should be investigated. To this end, the test was done by using a sample of 5 Chinese banks between 2003 and 2013 to examine the hypothesis "E-banking could improve the performance of Chinese banks in the long term", Secondly, this study examined the development stage and maturity stage of e-banking in China. The research question is "Does the e-banking really improve the bank performance in China", and the following hypotheses were justified.

\subsection{Proposed Hypothesis}

H0: E-banking could improve the performance of Chinese banks in the long term.

H1: E-banking could not improve the performance of Chinese banks in the long term.

\section{Literature Review}

\subsection{Internet Banking Adoption in Other Countries}

Polasik and Wisniewski (2009) indicated that the internet can currently be considered as the cheapest distribution channel for standardized bank operations, such as account services or fund transfers. From 1999, the number of internet banking users increased significantly. For instance, there were seven million users in 1999 in US. In addition, Deutsche Bank Research (2011) illustrated that e-banking adoption in Europe is rising. In Europe, the northern European countries enjoy highest adoption rates which reach 83 percent. Germany, France and UK constitute a second cluster with a rate being between 43 and 53 percent. USA has an e-banking adoption rate of 45 percent. Similar to western countries, in Turkey shows an increasing number of people who adopt e-banking (Onay \& Ozsoz, 2013). Onay and Ozsoz (2013) described that with the increasing number of e-banking users, half of the 32 deposit banks provide e-banking services. In the past decade in China, e-banking develops sharply in developing countries (Akinci, Aksoy, \& Atilgan, 2004). The research of Akinci et al indicated that regarding consumers' attitudes and adoption of e-banking, there were significant differences between e-banking users and non-e-banking users in terms of attitudinal properties, demographic profiles, and preferences for service delivery channels. Lu, Liu, Jing, and Huang (2005) revealed that China's entrance into the WTO makes the banking environment more competitive. While above these papers presented that internet banking has been widely applied and highly recognized in some countries, relatively little of the research has emphasized the impact of internet banking adoption on the banking industry in China. It is a great opportunity to investigate whether the adoption of e-banking can improve the performance of Chinese banks by providing empirical evidence.

\subsection{The Pros and Cons of E-Banking}

Existing literatures demonstrated that the e-banking brings many benefits to the banking institutions. For instance, the benefits accruing to a bank can be cost saving, increased number of clients, more service for customers, greater efficiency, and an enhancement of bank's reputation (Jayawardhena, \& Foley, 2000; Cheng, Lam, \& Yeung, 2006; Laukkanen, Sinkkonen, Kivijärvi, \& Laukkanen, 2007).

Banks can save their operational cost. Jayawardhena and Foley (2000) claimed that Internet delivery is cheaper than physical branches delivery. The cost saving arises through the combined effects of reduction and better utilisation of the workforce, equipment, space and operational savings. Similar to Jayawardhena and Foley, Cheng et al. (2006) argued that banks can benefit from much lower operating costs by offering internet banking services, which requires less staff and fewer physical branches. For instance, based on a sample of a Polish bank, Polasik (2006) estimated that the costs of internet and in-branch bank transfers were e 0.08 and e 0.46 respectively. However, Hernando and Nieto (2007) indicated that no academic work has demonstrated that Internet banking can systematically lower fixed costs.

Banks can gain access to new clients and serve more customers. Jayawardhena and Foley (2000) demonstrated that e-banking attracts new clients and retains existing clients with new products and services. In order to cater to different demographic segments, most banks use multiple distribution channels. This may be easier to sell financial services and secure a greater number of customers. Besides, Lassar, Manolis and Lassar (2005) and 
Laukkanen et al. (2007) indicated that the bank can serve more clients, because it can provide the customers with a convenient and inexpensive access to almost any type of banking transactions at the click of mouse, except the withdrawal service for 24 hours a day and seven days a week.

Banks can enhance their value, Devi Juwaheer, Pudaruth, and Ramdin (2012) claimed that banks can highlight benefits of internet banking in their promotion and advertising activities. These benefits include 24 hours accessibility, ability to self-manage and secure financial transactions conveniently at home, and availability of add-on services. All of these features could be used to promote the bank brand and enhance their value.

Despite the immense interests in the study of e-banking which can bring many benefits to banks, a considerable number of studies have been investigated in shortcomings of the e-banking adoption. Banks may encounter the new challenges and the main issues are competition, risk management and cost in some parts (Kolodinsky \& Hogarth, 2004; Yang et al., 2009).

Banks face more intense competition. Angelakopoulos and Mihiotis (2011) identified that more intense competition emerges with the appearance of internet banking in the research on electronic commerce. The reason is that every client can easily access the web sites of all banks without spending plenty of time. Hence they can compare the same service and products among different banks so as to decide the best one.

Banks face high level of risk. Kolodinsky and Hogarth (2004) observed that before customers use the internet banking service, they must provide numerous personal information. Moreover, Ibrahim, Joseph and Ibeh (2006) explicated that privacy is basic for the Electronic Service Quality standard. Hence, banks face a high risk of keeping customers' privacy. In addition, banks need to manage the security risk. When customers use internet banking, they must supply the authentications, such as user name and PIN. Furthermore, banks need to manage the reputation risk caused by unauthorized activities of customer accounts and the failure to provide reliable service. Angelakopoulos and Mihiotis (2011) proposed that new regulations and directions increased the level of management risk.

Banks face an increased cost of time and money. Firstly, banks need to spend time and money on e-banking service promotion to attract customers. Moreover, banks need to train the staffs responsible for the operation of e-banking channels (Angelakopoulos \& Mihiotis, 2011). Aggelis argued that compared with the normal staff, members in the e-banking department are required to have a strong background in technology. However, banks might face the challenge of recruiting talented people and the increasing cost of staff training as well. Aside from this, a single study stressed that banks have to spend money on e-banking system and infrastructure. Not only are the initial costs used for designing and establishing e-banking systems, but also the costs are applied for maintaining and updating systems and software (Angelakopoulos \& Mihiotis 2011).

\subsection{The Relationship Between Internet Banking Adoption and Bank Performance}

The change of internet technology is profound, particularly in the global banking industry. Internet as a tool can cross the traditional boundaries to define customer, market, and product. Banks act vital roles in financial intermediation, because banks need to undertake the risk of finding ways to leverage customer deposits and banks' liabilities, and the internet has opened new ways of exerting this function. Much research has addressed the potential impact of the internet on many different industries including the banking industry. However, earlier studies did not clearly show the relationship between internet banking and bank performance (Callaway, 2011). According to Malhotra and Singh (2009), Egland, Furst, Nolle and Robertson (1998) did the first study in 1998 which investigated 8,983 banks in US in order to analyse the performance and structure of banks, but they failed to show the relationship between internet banking and bank performance. Similarly, Furst et al. investigated 2,517 national banks in US for four times from 2000 to 2002. They found that compared with non-internet banks, those with internet banking gradually gained more profits. However, internet banking was a small factor influencing bank performance. Hence, no systematic evidence indicated the relationship between internet banking and bank performance.

In contrast, DeYoung (2001) did a study for three times to analyse the relationship between internet banking and bank performance. He observed that pure-play internet banks had poor financial performance but higher assets. After that, Hasan, Maccario, and Zazzara (2002) analysed 105 banks by using the data collected from 1993 to 2000 in Italy and observed that the banks with internet banking outperformed those with non-internet banking. However, we still know very little about the actual impact of internet banking on bank performance (DeYoung, 2005). Until 2007, Hernando and Nieto (2007) demonstrated that internet banking has a positive impact on bank performance. In particular, the bank with physical branches and internet banking has better performance in return on equity (ROE), return on assets (ROA), commission income and general expense. 
Internet banking adoption and bank performance Sullivan (2000) analysed the banks in Kansas (a city in United States) and reported that multichannel banks tend to add non-interest expenses to compare with non-internet banks. This could be translated into the fact that internet banks have poor profits. During the study, he found that return on average assets cannot be a variable to examine the profitability of banks, because sometimes internet banks are higher in this dimension than non-internet banks and sometimes are not. However, return on equity tends to be higher on average. Consequently, due to the limitation of time, the result of Sulliivan is not significant evidence to show the relationship between e-banking and banks' profitability. The time is too early to analyse internet banking that just start. In contrast, the study of Hernando and Nieto (2006) reported that after 3 years of adoption of internet banking, adoption banks have obvious more profitability than that without internet banking by using ROA and ROE, loan to total assets and etc. as variable. They observed 72 commercial banks in Spain to examine the internet banking impact on bank performance over the period 1994-2002, and they found that more time is needed to develop e-banking. The influence on profitability could be significant after three years, but in the earlier years, the impact is weak. Furthermore, they identified that the adoption of internet banking in Spain can be compared with that in US. Until 2002, apart from one medium size bank, all large and medium banks have adopted internet banking as a delivery channel. They could gain profit by extending the internet banking services as a substitute for traditional banking services.

Findings of Hernando and Nieto confirmed those of DeYoung, Lang and Nolle (2007) who reported that internet banking could improve bank's profitability. DeYoung et al. (2007) identified 424 community banks which adopt internet banking and 5,157 banks without internet banking in the United States and compared the changes between 1999 and 2001. They examined the banks from three aspects: income statement items (ROA and ROE), asset and liability in balance sheet. The results found that bank's profitability can be enhanced by adding the internet delivery channels and can especially increase income through charging deposits services and additional fee-based services. In addition, internet banking could be a product innovation to improve the quality of traditional banking products and a process innovation that has changed the way of checking accounts and deposit. Recently, in most community banks, transactional websites have become standard delivery channels.

In addition, Hasan et al. (2002) tracked the different types of banks in Italy over 10 years to analyse their performance, and they found that there is a strong correlation between the banks' offering internet banking and their performance. Moreover, their results showed that there is a significant positive relation between banks' profitability and internet banking practices. However, they also indicated that the negative relation between the use of internet baking and the risk cannot be ignored.

\section{Research Method}

Business research is a scientific method including developing idea and theory, defining problems, searching for and collecting information, analysing data, and discussing the findings and their implications (Zikmund, 2010). Similar to the majority of literature in this field (Abaenewe, Ogbulu, \& Ndugbu, 2013; Yang et al., 2009; Callaway, 2011), this study aims at building the correlation between e-banking and bank performance, especially in terms of profitability. Therefore, the results of this research will be presented as numerical data.

\subsection{Method of Data Collection}

Data can be gathered from primary or secondary data. This study used documentary secondary data including text data (such as reports to shareholders, notices and public records) and non-text materials (such as voice and video recordings). Sekaran and Bougie (2009) also presented that secondary data include books, statistical abstracts, data bases, annual reports of companies, etc. A database is a collection of raw data arranged logically and organised in a form that can be stored and processed by a computer (Zikmund, 2010). As Smith (2008) indicated that the secondary data are often of higher quality than that gathered by your own. Meanwhile, they save the cost and time spent in acquiring information (Sekaran \& Bougie, 2009). Therefore, the financial data that are collected from the annual report in this research could be accurate and creditable. In this research, secondary data are based on the Bloomberg database and financial reports of sample banks that have been released in their annual reports. The data collected cover the period from 2003 to 2013.

\subsection{Sample Selection}

In this research, stratified random sampling is applied. Stratified sampling requires that the population should have one feature or criterion to be identified as the sample (Bryman \& Bell, 2007). This study is searching for the impact of e-banking on bank performance. Thereby, the selection of banks needs to meet these criteria. Firstly, the bank should have a major share in E-banking market. In addition, they have enough financial data to be analysed. Apart from these, they need to have clear statements of e-banking department in their annual reports. The sample in this study will cover the period of 2003-2013. Then, the Bank of China, Industrial and 
Commercial Bank of China, Ping An Bank, Shanghai Pudong Development Bank and China Construction Bank are randomly selected as samples in this research.

\subsection{Data Analysis}

Based on the literature review, the author would analyse the data using SPSS and Excel from two aspects: banks' profitability and cost efficiency (Khrawhish \& Al-Sa'di, 2011; DeYoung, 2007; Hernando, 2007).

\subsection{Profitability}

When measuring the bank performance, the profitability of banks will be measured by evaluating return on assets, return on equity, and profit margin. According to Lee and Kim (2013), ROA and ROE are traditional ratios to measure banks' profitability, and can be calculated easily by using public information.

$$
\text { ROA }=\text { Net income after taxes } / \text { Total Assets }
$$

Return on assets (ROA) is a reliable indicator of the profitability of a company. ROA is related to total assets and gives an idea of generating profits by managing assets efficiently. It is presented in percentage

$$
\text { Return on Equity = Net Income/Shareholder's Equity }
$$

Return on equity (ROE) is another indicator of a company's profitability by calculating the financial return with the money shareholders who have invested (Lee \& Kim, 2013).

\section{Net interest margin $=$ net interest income/ total assets \\ Operating margin=net income/revenue}

ROA and ROE are good metrics for measuring the banks' profitability. Moreover, net interest margin is also a key indicator of the bank's profitability. It indicates that banks generate profits by borrowing and lending funds. In addition, operating margin is chosen in this study to measure the profitability.

\section{Cost Efficiency}

\section{Efficiency ratio= Non-interest expense/ revenue}

The efficiency ratio could measure the bank's ability to turn overhead into revenue. It is presented in percentage. If the percentage is lower, the bank does well. It either means a growth in revenue or a decrease in cost (Vitex, 2013).

\section{Data Analysis and Discussion of Findings}

This study presented the data of sample banks from 2003 to 2013 in China, analysed the data by SPSS and excel, and discussed the results, and then t-test was used to test the hypothesis.

\subsection{T-Test Instrument}

A t-test was done to see if there were any significant differences in the means of two groups on a particular interval-scaled or ratio-scaled variable interest. The t-test considered the means and standard derivations of the two groups on the variable and examined if the numerical difference in the means was significantly different from zero as postulated in our null hypothesis. It not only can be used to examine the mean differences between two different groups on a variable, it also can be used to compare the differences in the same group before and after a treatment (Sekaran \& Bougie, 2003).

In order to compare means, three kinds of t-test can be used: one-sample, paired-samples and independent-samples t-test. In this study, independent-samples t-test has been applied. Independent-samples t-test could compare means of a particular variable in different groups (Wagner, 2007). In this paper, the difference between two groups -the developing stage and developed stage of electronic banking should be analysed. When statistics such as a t-test are done, a null hypothesis is being tested. That is, researchers are testing the hypothesis that there is no difference between the two groups against the alterative or research hypothesis. The result of the test either will support or reject the null. The null hypothesis is rejected when the research hypothesis is true and therefore the intervention works; in scientific terms, a hypothesis can be supported, but never proved (Connelly, 2011).

\subsection{Descriptive Statistic of Variables}

Table 1 showed the descriptive statistics for the five variables that would be used to test the hypotheses in this study from 2003 to 2013. The number of data, minimum, maximum, mean and standard deviation value are presented. Mean is the most common measure that can measure the central tendency, and then get the balance point in a series of data. Standard derivation shows the distribution of all the values in the data (Berenson, 2006). 
However, due to the missing record in the Bloomberg, some secondary data are missed.

Table 1. Descriptive statistics from 2003 to 2013

\begin{tabular}{lccccc}
\hline & $\mathrm{N}$ & Minimum & Maximum & Mean & Std. Deviation \\
\hline Return on Assets & 52 & .04 & 1.39 & .8560 & .38000 \\
Return on Equity & 52 & 1.24 & 35.77 & 16.4794 & 6.63012 \\
Operating Margin & 52 & 5.46 & 56.75 & 41.2310 & 12.82508 \\
Efficiency Ratio & 49 & 25.01 & 62.43 & 44.2239 & 7.39484 \\
Net Interest Margin & 51 & 2.07 & 3.88 & 3.0488 & .35365 \\
Valid N (listwise) & 49 & & & &
\end{tabular}

Source from: Bloomberg (2014).

According to the table 1 above, the mean of return on assets ratio (ROA) is $0.86 \%$ and the minimum and maximum figure is $0.04 \%$ and $1.39 \%$ respectively. Regarding the return on equity ratio (ROE), the mean is $16.48 \%$ and the minimum and maximum is $1.24 \%$ and $35.77 \%$ separately. Additionally, the maximum figure of operating margin $(\mathrm{OM})$ is $56.75 \%$, the minimum one is $5.46 \%$. Then, the mean is $41.23 \%$. For the efficiency ratio, the average is $44.22 \%$ where minimum and maximum is $25.01 \%$ and $62.43 \%$ severally. On average, the net interest margin (NIM) ration is $3.05 \%$ and maximum and minimum is $3.88 \%$ and $2.07 \%$ respectively. The gap between minimum and maximum reveals that banks generate significant changes during to the process of adoption e-banking. Furthermore, compared with other variables, operating margin $(12.83 \%)$ is the largest standard deviation. This means that OM has more significant variance than other variables. Moreover, the ROE and efficiency ratio also have larger standard deviation with $6.63 \%$ and $7.39 \%$ separately. This indicates that ROE and efficiency ratio have obvious changes during 2003 to 2013.

\subsection{Data Presentation and Analysis}

In this part, we presented and analysed the data with all variables-ROA, ROE, operating margin, efficiency ratio and net interest margin respectively between developing stage and developed stage of e-banking. In addition, the result of the test of hypothesis by independent-samples t-test would be analysed.

\subsubsection{Return on Assets (ROA)}

Table 2 presented the ROA in two groups- developing stage and developed stage. The mean of ROA in developed stage is larger than that in developing stage, and the difference is -.44472. It indicated that with the development of e-banking, banks could generate more profits by managing assets. This is probably because the development of e-banking phase has gone, and it covers 7 years from 2003 to 2010. However, although the developed stage lasted four years, the data of ROE for samples banking only can be found for two or three years. Meanwhile, during the development of e-banking, the performance was unstable. Additionally, standard error mean is used to estimate the standard deviation of the sampling distribution of the mean, and it is a useful statistic in t-test (Hinton, 2003). For the ROA, all groups have little standard error mean. The adequate sample banks from 2003 to 2013 may lead to the result. In addition, Table 2 presented the result of independent-samples t-test for ROA. The table showed that the Levene's $F$ is significant (13.136), and the significance is less than .001 . Hence, the result of equal variances not assumed would be accepted. Thus, for ROA, the appropriate $t$ $=-5.98$, degrees of freedom $(\mathrm{df})=49.81$, mean difference $=-.44472$ and $\mathrm{p}=.000$. Due to $\mathrm{p}<.05$, the developing stage is significantly different from developed stage on ROA.

In summary, the results of t-test indicated that developing phase and developed phase of e-banking were obviously different in terms of ROA. In addition, the performance of e-banking in developed stage was better than developing stage.

\subsubsection{Return on Equity (ROE)}

The mean of ROE in developed stage is obviously different from that in developing stage, and the mean difference is -4.33914 . The difference of mean indicated that banks could generate more profits with the shareholders' investment in the developed stage of e-banking. In addition, the standard deviation showed that the developing stage is wider, due to the same reason with ROA.

Similar to the result of ROA, the Levene's F of ROE is significant 10.437, and the significance of Levene's test is less than .002 . Hence, the result of equal variances not assumed will be accepted. Thus, for ROE, the appropriate $\mathrm{t}=-3.128$, degrees of freedom $(\mathrm{df})=44.086$, mean difference $=-4.33914$ and two-tailed $\mathrm{p}=.003$. For the one-tailed level, the $\mathrm{p}=0.015$. Due to $\mathrm{p}<.05$, the developing stage is significantly different from developed 
stage on ROA. In summary, the results of t-test indicated that developing phase and developed phase of e-banking are obviously different in terms of ROE. In addition, the e-banking in developed stage has better performance than that in developing stage.

\subsubsection{Operating Margin}

When the e-banking is in developing stage, the mean operating margin score is 36.6817 (Table 2) and the standard deviation of operating margin score is 12.90927. For the e-banking of developed stage, the mean operating margin score is 50.5971 and the standard deviation of operating margin is 5.62855. Moreover, the mean difference is -13.91534 . This indicated that during the developed stage of e-banking, the banks could gain more profits.

The significance of Levene's test for equality of variances is greater than 0.05 , which here is 0.09 . Hence, the information of equal variance should be used. For equal variance, $t$ is -4.236 , which with 49.658 degrees of freedom is significant at .000 for the two-tailed level.

Consequently, the results of t-test indicated that in terms of operating margin ratio, developing phase and developed phase of e-banking are significantly different. In addition, the e-banking in developed stage could gain more profits than that in developing stage.

\subsubsection{Efficiency Ratio}

Furthermore, the Table 2 also presented that the mean of e-banking in developing stage in terms of efficiency ratio is 44.9934 and that in developed stage is 42.3000 . In other words, e-banking in developed stage performs better than that in development stage. Due to the smaller efficiency ratio, the banks have less non-interest expense, or more revenue. However, the difference is not obvious, and the mean difference is 2.69343. Similar to the result of mean, the standard deviation of developing stage and developed stage are not significantly different, which is 7.81138 and 6.06166 respectively.

Levene's test for equality of variance about efficiency ratio indicated that the variances are equal because the $p$ value of .898 is not statistically significant. Therefore, the $t$ value for operating margin is 1.156 , which with 47 degrees of freedom has an accurate two-tailed significance level of .254. Then, the p value of one-tail level is .127 , greater than 0.05 . Therefore, the difference between two groups is in a small extent.

To conclude, there is a gap between developing stage and developed stage group, and groups in the developing stage perform better. However, the gap is so small that the difference is not significant between two groups.

\subsubsection{Net Interest Margin (NIM)}

In developing stage, the mean of net interest margin score of the e-banking is 3.0557 (see the Table 2) and the standard deviation score is .39775. For the e-banking of developed stage, the mean of net interest margin score is 3.0338 and the standard deviation is .24075 . The mean difference between two groups is tiny, only .02196 . It may manifest that the interest income is a small factor for e-banking impact on banks' performance. Apart from the income from interest, other services may be more profitable for e-banking, such as investment securities service. However, with respect to NIM mean only, the performance in developing stage is better than that in developed stage.

In terms of net interest margin, the significance of Levene's test for equality of variances is less than 0.05 , which here is 0.039 . Hence, the information of equal variance should be rejected. For equal variance not assumed, $t$ value is .243 , which with 44.928 degrees of freedom is significant at .809 for the two-tailed level. Then, the one-tailed level of $\mathrm{t}$-test is 0.4045 , which is greater than 0.05 .

To sum up, e-banking has a negative impact on bank performance only in terms of net interest margin. Nevertheless, there is no significant difference between developing stage and developed stage of e-banking on net interest margin of Chinese banks. 


\subsection{Summary}

Table 2. The summary of all the variables

\begin{tabular}{|c|c|c|c|c|c|c|c|c|c|c|}
\hline \multirow[b]{2}{*}{ Groups } & \multicolumn{2}{|c|}{ ROA } & \multicolumn{2}{|c|}{ ROE } & \multicolumn{2}{|c|}{ OM } & \multicolumn{2}{|c|}{ ER } & \multicolumn{2}{|c|}{ NIM } \\
\hline & 1 & 2 & 1 & 2 & 1 & 2 & 1 & 2 & 1 & 2 \\
\hline Mean & .7106 & 1.1553 & 15.0609 & 19.4000 & 36.6817 & 50.5971 & 44.9934 & 42.3000 & 3.0557 & 3.0338 \\
\hline Mean Difference & \multicolumn{2}{|c|}{-.44472} & \multicolumn{2}{|c|}{-4.33914} & \multicolumn{2}{|c|}{-13.91534} & \multicolumn{2}{|c|}{2.69343} & \multicolumn{2}{|c|}{.02196} \\
\hline $\mathrm{F}$ & \multicolumn{2}{|c|}{13.136} & \multicolumn{2}{|c|}{10.437} & \multicolumn{2}{|c|}{7.306} & \multicolumn{2}{|c|}{.017} & \multicolumn{2}{|c|}{4.477} \\
\hline Sig. & \multicolumn{2}{|c|}{.001} & \multicolumn{2}{|c|}{.002} & \multicolumn{2}{|c|}{.009} & \multicolumn{2}{|c|}{.898} & \multicolumn{2}{|c|}{.039} \\
\hline $\mathrm{t}$ & \multicolumn{2}{|c|}{-5.981} & \multicolumn{2}{|c|}{-3.128} & \multicolumn{2}{|c|}{-4.236} & \multicolumn{2}{|c|}{1.156} & \multicolumn{2}{|c|}{.243} \\
\hline P(Sig.) & \multicolumn{2}{|c|}{.000} & \multicolumn{2}{|c|}{.003} & \multicolumn{2}{|c|}{.000} & \multicolumn{2}{|c|}{.254} & \multicolumn{2}{|c|}{.809} \\
\hline Conclusion & \multicolumn{2}{|c|}{ Positive } & \multicolumn{2}{|c|}{ Positive } & \multicolumn{2}{|c|}{ Positive } & \multicolumn{2}{|c|}{ Negative } & \multicolumn{2}{|c|}{ Negative } \\
\hline
\end{tabular}

The tests for difference between mean were conducted for e-banking in developing period and developed period for return on assets (ROA), return on equity (ROE), operating margin, efficiency ratio and net interest margin at $5 \%$ levels of significance.

On the one hand, the result revealed that there is obvious difference between developing stage and developed stage on ROA, ROE and operating margin. In addition, the result clearly showed that with the passage of time, the adoption of the e-banking in China has significantly improved Chinese banks' performance.

On the other hand, the result also demonstrated that there is no significant difference between developing stage and developed stage on efficiency ratio and net interest margin of Chinese banks on adoption of e-banking. However, these results showed negative influence of the adoption of e-banking on banks' performance as time goes on.

Due to the activities of banks after adoption of e-banking system, the operating costs of banks have increased sharply. Moreover, in the initial stage, the e-banking technology will spend huge capital to develop and maintain systems. Apart from these, there is increasing number of e-banking technology equipment, IT staff and employees who are trained to deal with e-banking issues. Consequently, the requirements increased the total costs of total assets of banks. However, the result above indicated that returns on assets are positive in the long run. Due to the convenience of e-banking, more clients have been attracted, and more online services have been accepted. Hence the net income rose dramatically. Compared with ROA, the net interest margin changed slightly. Although the interest income is an important part for banks' profitability, it has limited impact on bank performance with more and more online services arousing customers' interest.

\subsection{Compared with Empirical Results}

The result of this study echoes the study of Onay et al. (2013) that they tested the impact of e-banking on banks' profitability in Turkey in terms of NIM. They reported that the development of online banking was a gradual process, and internet banking had a negative impact on bank's performance in terms of NIM in Turkey after two years. However, they also found that there was a negative impact of internet banking adoption on bank profitability. The findings were different from Hernando and Nieto. Hernando and Nieto (2006) reported that after three-year adoption of e-banking, it showed positive impacts on Spanish banks in terms of ROA and ROE as variables. This also demonstrated that there is a lag period for the recovery from huge capital costs. In addition, DeYoung et al. (2007) who reported that internet banking could improve banks' profitability in terms of income statement items (ROA and ROE), asset and liability in balance sheet.

In comparison, Siam (2006) discovered that e-banking has a negative impact on banks' performance in the short run in Jordan in a similar study. He attributed it to the costs of the training of employees, and the maintenance of electronic infrastructure. Hence, in the short-term e-banking will have a negative influence. However, due to the innovation of technology, most banks will benefit greatly from providing electronic services in the long run. The study also shared similar opinions that banks will perform better in the long run on profitability level.

Furthermore, the findings were similar to the results obtained by Khrawish and Al-Sa'di (2011). They reported that banks with e-banking in Jordan could enhance the performance of banks on ROA and ROE. Moreover, there is no significant impact of e-banking on bank performance in terms of net interest margin. Nevertheless, the results of this study did not imply that e-banking is not necessary with respecting net interest margin. Banks improve their financial service delivery in order to satisfy customers. Moreover, e-banking creates more products and services for catering to customers. For customers, e-banking has obvious advantages. The most important one is convenience. Customers could pay online, shop online, and trade online. Furthermore, e-banking is 
24-hour available for most services. Thus, it is easier to check the account information or other updated information. In addition, due to the convenience and fast information delivery, e-banking could expand more products. Therefore, although e-banking has a tiny impact on the interest income, it will have a great impact on total income. In the study, for total operating, the great gap of operating margin means between developing stage and developed stage indicated that e-banking has a significant impact on bank performance.

Apart from these, similar to Hernando and Nieto (2007), the result of efficiency ratio indicated that e-banking influence is not obvious on banks' performance. It cannot be ignored that e-banking could improve the efficiency in some aspects for banks. For example, due to the lower transaction cost, the shifting from paper-based transaction to electronic one leads more people to choose electronic transaction (Kaur, 2013). As a result, banks will save an amount of time to deal with the transaction, and they also could improve the quality of other services that are offered in real offices. However, in this study, it shows a negative impact of e-banking on bank performance.

The null hypothesis in this study is "E-banking could enhance the performance of China banks in the long term", and the rejected hypothesis is "E-banking could not improve the performance of China banks in the long term". The study used five indicators to test the hypothesis. Among all the variables, the ROA, ROE and operating margin clearly demonstrated that e-banking had a significant impact on the performance of banks. In addition, the figures showed that e-banking could improve the banks' performance in the long term. In contrast, efficiency ratio and net interest margin failed to show a positive impact of e-banking on bank performance. However, although the difference between two groups was not obvious, the mean of NIM and efficiency ratio in developing period were greater than it in developed stage. In a word, e-banking had a slight negative effect on bank performance in terms of NIM and efficiency ratio

\section{Conclusion}

As mentioned in the literature review, most studies presented that the relationship between e-banking and bank performance was changing over time. Earlier researcher indicated that there was no significant relationship between e-banking and bank performance (Egland et al., 1998; Furst et al., 2000; Sullivan, 2000). As time went on, increasing number of researchers began to observe banks' performance. The year of banks' adoption of e-banking they analysed is longer. Hence, the data they gathered was more than prior researchers. The researchers who analysed the banks in developed countries stated that the relationship between e-banking and bank profitability was positive in the long term.

However, compared with other Asian countries, the development of e-banking is advanced in China. The author observed five banks' performance from 2003 to 2013. Then the variables were tested by t-test and analysed through SPSS and Excel. Ultimately, the hypothesis was examined. The results showed that e-banking had significantly positive impact on bank performance in terms of ROA, ROE and operating margin. In contrast, there was a slightly negative impact of e-banking on the performance of banks with respect to NIM and efficiency. Chinese banks adopted e-banking in 1999, later than western countries. Because of the benefits of e-banking both to customers and banks, banks valued the development and promotion of e-banking. Hence, the e-banking has grown rapidly from 1999 to 2010. In this research, the data analysis showed that e-banking could enhance bank performance in China.

\section{Implications of Research}

This study is valuable to commercial banks, because it gives empirical evidence of the relationship between e-banking and bank performance. They could analyse the impact of e-banking on banks' performance in terms of return on assets, return on equity, operating margin, efficiency and interest margin. Moreover, banks could predict future problems in the e-banking sector and take some precautions in advance. This research is important to banks who want to establish e-banking systems or improve e-banking services, as the empirical research and the findings of the study may help banks to note their defects. Moreover, it also caters to the person who is interested in e-banking, because the study had the basic information about e-banking.

\subsection{The Implication for Banking}

As mentioned in the literature review, there are many advantages for banks to develop e-banking. The main advantages are saving costs, attracting new customers, serving more clients and obtaining more opportunities. Moreover, e-banking is a platform for banks to expand their services and products. For e-banking, it has lower costs and multiple regions to serve customers. In other words, banks could expand their functions via e-banking. However, although the e-banking develops dramatically in China, the gap is significantly huge between China and western countries. With China's accession to World Trade Organization (WTO), domestic banks are facing 
fierce competition with foreign banks. Hence, commercial banks must develop their e-banking services to meet the challenges and enhance their core competitiveness. In comparison, with the rapid expansion of e-banking, some problems occur. The main important issue is lack of relevant laws. What internet banking follows is protocol. Banks solve problems through arbitration. Consequently, it increases the risk for customers on financial transactions. In addition, e-banking is affected by networks. The slow network will lead to the slow service of banks. As a consequence, it hinders the promotion of e-banking services (China Financial Net, 2005).

\subsection{Suggestions for Banks}

As what showed above, banks are facing some problems. In order to enhance the competence of banks, the author gives following recommendations based on the study.

1) Establish a customer-oriented business strategy. Banks stick to regarding customers as the centre, keep financial innovation ongoing, and improve their products and services. Banks should aim to make online trading more convenient, securer and less risky for customers.

2) Actively promote e-banking, attract more people to know, understand and accept online banking. Cultural and geographical constraints will prevent some people from using e-banking. Hence, banks enhancing the promotion of e-banking could attract more customers.

3) Establish and improve banks' network security systems. With the development of online banking, e-banking will face security problems. Enhance banks' network security systems to defend computer crime, computer virus, malicious intrusion and other financial fraud. Meanwhile, banks need to increase daily inspection and information reports to avoid massive errors.

4) Furthermore, China Banking Regulatory Commission should strengthen its supervision of financial risks on the Internet. The major purpose of government is to protect the consumers and enhance public confidence in the banking system.

\section{Limitations of the Study}

Although the study found evidence that contributes to the existing researches about all the ratios, it has some limitations. First of all, the time period that was used is not precise. This study divided the development of e-banking into three stages based on iResearch (2011). Although Research is for professional practice and professional banking industries, the development of e-banking in all banks is different. Hence, their maturing time is different. Nevertheless, it has little effect on the results, because the study examines the long run of e-banking development.

Moreover, we completed this research project in 2014. the findings of this study might not be applicable after 2016 due to the significant development of internet banking in China. The study only observed the data from 2003 to 2013, and analysed the two-stage developing and developed phase of e-banking since we lack information of earlier stage. Hence, the change of bank performance may not be significant in some areas. However, for long term of operating performance in e-banking, the results are appropriate. In addition, the sample banks are chosen at random. However, almost all of them are large banks and they cannot represent all Chinese banks. Hence, the findings may not be suitable for every bank. Furthermore, the ratios used in the research are not enough. According to the empirical researches, many ratios could be used to analyse the bank performance. However, in the study, limit ratios are selected to test the hypothesis.

This study focused on the impacts of e-banking on five variables- ROA, ROE, OM, NIM and efficiency to analyse the profitability and efficiency of banks. However, e-banking can also impact on many other performance, such as non-financial performance aspects and financial performance. Therefore, for further study of this topic, it is necessary to analyse other rations such as overhead and non-interest margin in different stages. Moreover, collecting more data of banks could help the research to predict the financial performance changes in the development of e-banking. Furthermore, due to more detailed analysis, the method of case study should be applied to examine the factors which will show the impact of e-banking on banks' performance.

\section{References}

Abaenewe, Z. C., Ogbulu, O. M., \& Ndugbu, M. O. (2013). Electronic banking and bank performance in Nigeria. West African Journal of Industrial and Academic Research, 6(1), 171-187.

Akinci, S., Aksoy, S., \& Atilgan, E. (2004). Adoption of internet banking among sophisticated consumer segments in an advanced developing country. The International Journal of Bank Marketing, 22(3), 212-219. https://doi.org/10.1108/02652320410530322

Angelakopoulos, G., \& Mihiotis, A. (2011). E-banking: challenges and opportunities in the Greek banking sector. 
Electronic Commerce Research, 11(3), 297-319. https://doi.org/10.1007/s10660-011-9076-2

Berenson, M. (2006). Basic business statistics: concepts and applications (12th ed). London: Pearson2012

Bryman, Al., \& Bell, E. (2007). Business research methods (2th ed). Oxford: Oxford University Press.

Callaway, S. K. (2011). Internet banking and performance. American Journal of Business, 26(1), 12-25. https://doi.org/10.1108/19355181111124070

Cheng, T. C., Lam, Y. C., \& Yeung, C. L. (2006). Adoption of internet banking: An empirical study in Hong Kong. Decision Support Systems, 42(3), 1558-1572. https://doi.org/10.1016/j.dss.2006.01.002

China Financial Net. (2005). Analysis of China's internet bank. iResearch View. Retrieved $16^{\text {th }}$ April 2014 from http://www.iresearchchina.com/

Connelly, L. M. (2011). T-tests. Medsurg Nursing, 20(6), 341. Retrieved from http://search.proquest.com/

Cooper, D. R., \& Schindler, P. S. (2014). Business research methods (12th ed). New York, NY: McGraw-Hill Education 2014.

Daniela, B., Simona, M., \& Paun, D. (2010). Electronic banking advantages for financial services delivery. Annals of Faculty of Economics, 1(2), 672-677.

Deutsche Bank Research. (2011). Update on online and mobile banking. Retrieved 20 $0^{\text {th }}$ April 2014 from http://www.dbresearch.de/PROD/DBR_INTERNET_DE-PROD/PROD0000000000279995.pdf

Devi, J. T., Pudaruth, S., \& Ramdin, P. (2012). Factors influencing the adoption of internet banking: a case study of commercial banks in Mauritius. World Journal of Science, Technology and Sustainable Development, 9(3), 204-234. https://doi.org/10.1108/20425941211250552

DeYoung, R. (2001). The Financial Performance of Pure Play Internet Banks, Economic Perspectives, 25(1), 60-75.

DeYoung, R. (2005). The Performance of Internet-based Business Models: Evidence from the Banking Industry, Journal of Business, 78(3), 893-947. https://doi.org/10.1086/429648

DeYoung, R., Lang, W., \& Nolle, D. (2007). How the Internet affects output and performance at community banks, Journal of Banking \& Finance, 31(4), 1033-1060. https://doi.org/10.1016/j.jbankfin.2006.10.003

Egland, K. L., Furst, K., Nolle, D. E., \& Robertson, D. (1998). Banking over the Internet. Quarterly Journal, 17(4).

Furst, K., Lang, W. W., \& Nolle, D. E. (2002). Internet banking. Journal of Financial Services Research, 22(1), 95-117. https://doi.org/10.1023/A:1016012703620

Hasan, I., Maccario, A., \& Zazzara, C. (2002). Do Internet Activities Add Value? The Italian Bank Experience, Working Paper, Berkley Research Center, New York University.

Hernando, I., \& Nieto, M. (2006). Is the Internet Delivery Channel Changing Banks'Performance? The Case of Spanish Banks. Banco de Espana Research Paper No. WP-0624. https://doi.org/10.2139/ssrn.930563

Hernando, I., \& Nieto, M. J. (2007). Is the Internet Delivery Channel Changing Bank's Performance? The Case of Spanish Banks. Journal of Banking and Finance, 31(4), 1083-1099. https://doi.org/10.1016/j.jbankfin.2006.10.011

Hinton, P. R. et al. (2004). SPSS explained. Hove: Routledge.

Ibrahim, E., Joseph, M., \& Ibeh, K. (2006). Customers' perception of electronic service delivery in the UK retail banking sector. International Journal of Bank Marketing, 24(7), 475-493. https://doi.org/10.1108/02652320610712094

iResearch. (2011). China online banking research report 2010-2011. Retrieved 22 ${ }^{\text {th }}$ December 2013 from http://www.iresearchchina.com/

Jayawardhena, C., \& Foley, P. (2000). Changes in the banking sector - The case of Internet banking in the UK. Internet Research, 10(1), 19-30. https://doi.org/10.1108/10662240010312048

Kaur, R. (2013). The Impact of Electronic Banking on Banking Transactions: A Cost-Benefit Analysis. IUP Journal of Bank Management, 12(2), 62-71.

Khrawish, H. A., \& Al-Sa'di. (2011). The Impact of E-banking on Bank Profitability: Evidence from Jordan, Middle Eastern Finance and Economics, (13), 142-158. 
Kolodinsky, J. M., \& Hogarth, J. M. (2004). The adoption of electronic banking technologies by US consumers. The International Journal of Bank Marketing, 22(4), 238-259. https://doi.org/10.1108/02652320410542536

Kondabagil, J. (2007). Risk management in electronic banking: Concepts and best practices. Singapore; Hoboken, NJ: John Wiley \& Sons Asia. https://doi.org/10.1002/9781118390436

Kurnia, S., Peng, F., \& Liu, Y. R. (2010). Understanding the adoption of electronic banking in China. In 2010 43rd Hawaii International Conference on System Sciences (HICSS) (pp. 1-10). IEEE. https://doi.org/10.1109/HICSS.2010.421

Lassar, W. M., Manolis, C., \& Lassar, S. S. (2005). The relationship between consumer innovativeness, personal characteristics, and online banking adoption. International Journal of Bank Marketing, 23(2), 176-199. https://doi.org/10.1108/02652320510584403

Laukkanen, P., Sinkkonen, S., Kivijärvi, M., \& Laukkanen, T. (2007). Consumer Resistance and Intention to use Internet banking service. Proceedings of the EBRF Conference, Jyväskylä, Finland

Lee, J. Y., \& Kim, D. (2013). Bank performance and its determinants in Korea. Japan and the World Economy, 27, 83-94. https://doi.org/10.1016/j.japwor.2013.05.001

Lu, M. T., Liu, C. H., Jing, J., \& Huang, L. J. (2005). Internet banking: strategic responses to the accession of WTO by Chinese banks. Industrial Management and Data Systems, 105(3), 429-443. https://doi.org/10.1108/02635570510592343

Malhotra, P., \& Singh, B. (2009). The impact of internet banking on bank performance and risk: The Indian experience. Eurasian Journal of Business and Economics, 2(4), 43-62.

Mihalciuc, C. C., Apetri, A. N., \& Bonaventure, M. (2008). The importance of modern e-banks for development of new economy. The USV Annals of Economics and Public Administration, 8(1), 147-151.

Onay, C., Ozsoz, E., \& Helvacioglu, A. D. (2013). The Impact of Internet-Banking on Brick and Mortar Branches: The Case of Turkey. Journal of Financial Services Research, 2(44), 187-204. https://doi.org/10.1007/s10693-011-0124-9

Polasik, M. (2006). Bankowosc elektroniczna. Istota - stan - perspektywy, CeDeWu, Warszawa.

Polasik, M., \& Wisniewski, T. P. (2009). Empirical analysis of internet banking adoption in Poland. International Journal of Bank Marketing, 27(1), 32-52. https://doi.org/10.1108/02652320910928227

Rauf, H. (2014). Trends in China's E-commerce Market. Retrieved from http://www.china-briefing.com/news/2014/06/04/trends-chinas-e-commerce-market.html

Sekaran, U., \& Bougie, R. (2003). Research methods for business a skill-building approach (4th ed). New York: Wiley.

Sekaran, U., \& Bougie, R. (2009). Research methods for business a skill-building approach (5th ed). Chichester: Wiley.

Siam, A. Z. (2006). Role of the Banking Services on the Profits of Jordanian Banks. American Journal of Applied Science, 3(9), 1999-2004. https://doi.org/10.3844/ajassp.2006.1999.2004

Smith, E. (2008). Using secondary data in educational and social research. Maidenhead: McGraw-Hill Open University Press2008.

Sullivan, R. J. (2000). How Has the Adoption of Internet Banking Affected Performance and Risk at Banks? A Look at Internet Banking in the Tenth Federal Reserve District. Financial Industry Perspectives, 1-16.

Sumra, H. S. (2011). The Impact of E-Banking on the Profitability of Banks: A Study of Pakistani Banks. Journal of Public Administration and Governance, 1(1), 31-38. https://doi.org/10.5296/jpag.v1i1.692

Yang, J., Cheng, L., \& Luo, X. (2009). A comparative study on e-banking services between China and USA. International Journal of Electronic Finance, 3(3), 235-252. https://doi.org/10.1504/IJEF.2009.027848

Zikmund, W. G. (2010). Business research methods (9th ed.). Mason, Ohio: South-Western. 


\section{Appendix}
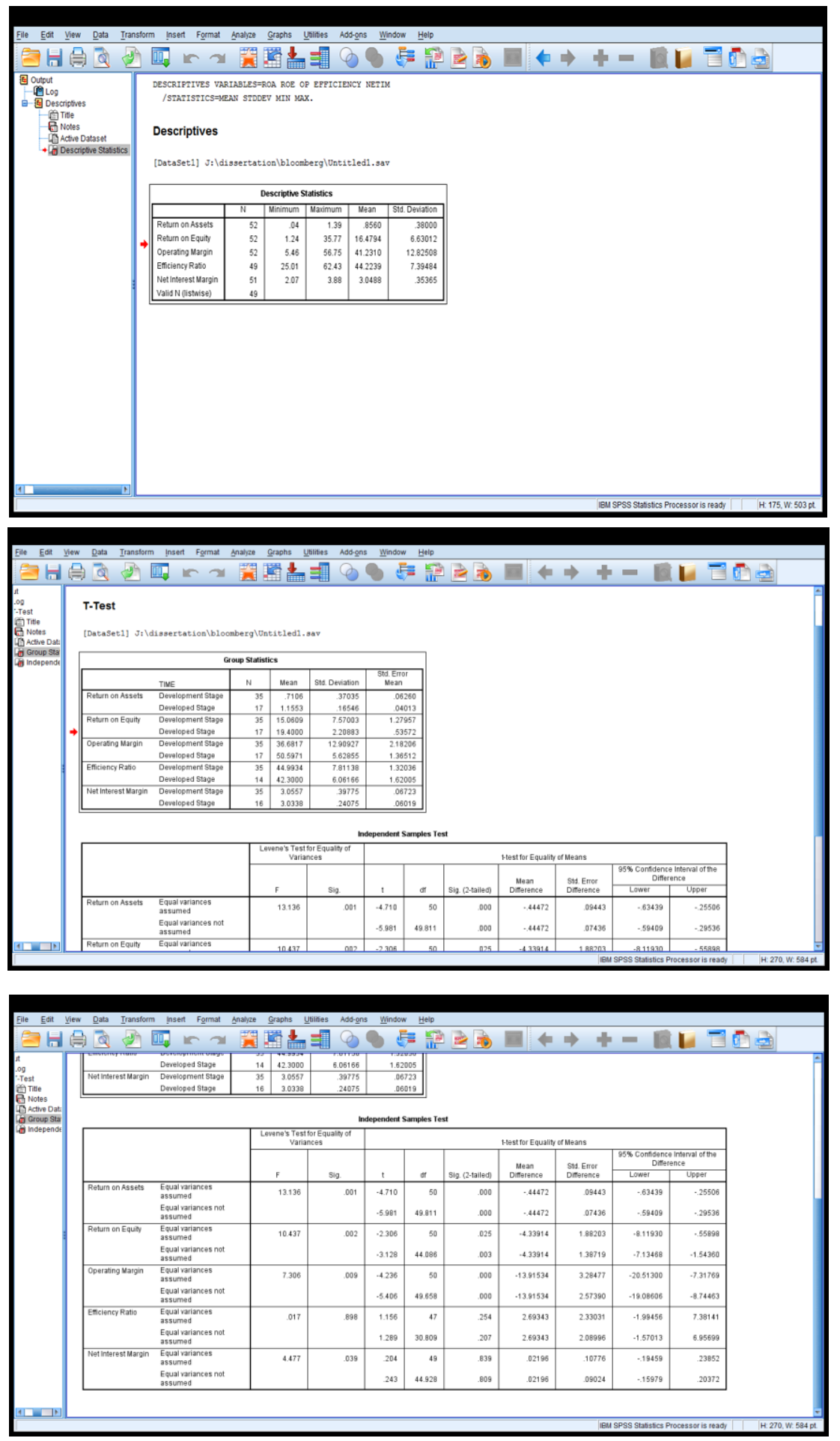

\section{Copyrights}

Copyright for this article is retained by the author(s), with first publication rights granted to the journal.

This is an open-access article distributed under the terms and conditions of the Creative Commons Attribution license (http://creativecommons.org/licenses/by/4.0/). 